\title{
Variation in the diet of Cassin's auklet reveals spatial, seasonal, and decadal occurrence patterns of euphausiids off California, USA
}

\author{
David G. Ainley ${ }^{1, * * *}$, Larry B. Spear ${ }^{1, *, *}$, Sarah G. Allen $^{2}$

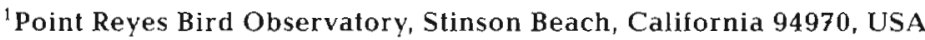 \\ ${ }^{2}$ National Park Service, Point Reyes Station, California 94956, USA
}

\begin{abstract}
We investigated spatial and temporal variation in the diet of a planktivore, the Cassin's auklet Ptychoramphus aleuticus, in the Gulf of the Farallones, California, USA, where its population has decreased ca $50 \%$ in size coincident with the general decline of zooplankton in the California Current. Stomach samples were collected and compared among birds foraging at sea during the nonupwelling, post-spring transition (to upwelling), and upwelling periods each year from 1985 to 1988. Upwelling-period samples also were compared with samples regurgitated to chicks on the Farallon Islands during that period; such samples had been collected during 1971 and 1977-1991 During the non-upwelling period, auklets fed on the small, energetically inferior, oceanic euphausiid Euphausia pacifica, but following the spring transition, the auklets switched to small, juvenile fish (mostly Sebastes spp.) until these had grown too large for capture. Thereafter, the auklets switched to the larger and energetically more valuable euphausid Thysanoessa spinifera, which had become available upon the onset of upwelling. This general pattern was repeated each year, although some betweenyear variability among ancillary prey was evident. Auklet foraging locality, however, varied only slightly throughout the year; auklets were most dispersed during El Nino. It was apparent that the availability of $T$. spinifera was linked to upwelling. The decrease in the prevalence of $T$. spinifera in the diet fed to chicks from 1971 to 1991 is consistent with decreased intensity of upwelling in the region, as is the reduction in numbers of auklets in the region over the same period. Our results indicate the value of studies of easily accessible marine predators, which can temporally and spatially integrate patterns in the prevalence of prey species, thereby increasing our understanding of the important processes that structure food webs.
\end{abstract}

KEY WORDS: California Curront Cassin's auklet Diet Euphausia pacifica Euphausid Interannual variability. Thysanoessa spinifera. Upwelling

\section{INTRODUCTION}

Marine birds are sensitive to perturbations in marine climate, food-web structure, and prey availability (e.g. Crawford \& Shelton 1978, Glantz \& Thompson 1981. Furness \& Monaghan 1985, Barber \& Chavez 1986. Monaghan et al. 1989a, b, Ribic et al. 1990, Cairns 1992, Ainley et al. 1995a). Seabirds, in fact, have proven useful as indicator species (Furness \& Green-

\footnotetext{
-E-mail: htharvey@ix.netcom.com

- Present address: H.T. Harvey \& Associates, PO Box 1180, Alviso, California 95002, USA
}

wood 1993) among the top-trophic-level species owing to their (1) great mobility and quick response to anomalies; (2) large numbers, thus facilitating quantification of patterns; and (3) workability (highly visible and accessible). In most cases, however, much additional work is required to detail the actual trophic pathways and other factors that link avian predators directly to food-web processes (e.g. Hunt et al. 1991).

Numerous studies in the Califormia Current upwelling system in the eastern Pacific indicate that the euphausiids Thysanoessa spinifera and Euphausia pacifica are key species in the middle portions of continental shelf and slope food webs, respectively. These 
are the main prey species during summer of such numerically dominant predators as squid Loligo opalescens, Pacific whiting Merluccius productus, rockfish Sebastes spp., jack mackerel Trachurus symetricus, salmon Onchorhynchus spp., humpback whales Megaptera novaeangliae and various seabirds (Phillips 1964, Alversen \& Larkins 1969, Karpov \& Cailliet 1978, MacCall et al. 1980, Chu 1982, Peterson et al. 1982, Ainley \& Boekelheide 1990, Kiekeffer 1992, Reilly et al. 1992). Yet studies on the spatial and temporal variability of euphausiids in the coastal portion of the California Current are disappointingly few (e.g. Smith \& Adams 1988). They receive neither the attention of biological oceanographers, mainly interested in primary production, nor that of fishery oceanographers, constrained to problems directly related to commercial fisheries. A unique $22 \mathrm{yr}$ time series of data on the reproductive phenology, diet, and demography of the Cassin's aukiet Ptychordmpins aleuticus shows the sensitivity of this zooplanktivorous seabird to the availability of prey (Ainley \& Boekelheide 1990, Ainley et al. 1995a). The Cassin's auklet is one of the most abundani resident seabirds of the California Current region (Ainley \& Boekelheide 1990, Carter et al. 1992).

Zooplankton abundance, in response to changed ocean climate, has been declining in the California Current (Roemmich \& McGowan 1995), and numbers of zooplankton-feeding seabirds (Roemmich \& McGowan 1995, Ainley et al. 1995b), including Cassin's auklets (Ainley et al. 1994), have also declined. The purpose of the present paper is to analyze the annual pattern of prey use of this strictly planktivorous species, to identify links between its natural history and that of its zooplankton prey, and to describe the relationships of the links to ocean processes (see hypothesis below).

\section{LINK BETWEEN AUKLETS, EUPHAUSIIDS, AND UPWELLING}

The diets fed to Cassin's auklet chicks have been studied by Manuwal (1974) and Ainley \& Boekelheide (1990) at the Farallon Islands off California, and by Vermeer (1981, 1985) at coastal islands off British Columbia. Thus, the euphausiid-dominated diet during summer is fairly well known, considering that adults eat the same prey as that fed to chicks (Manuwal 1974, author's pers. obs.). Thysanoessa spinifera is a major component of this diet and may be critical to the life history of the Cassin's auklet. Vermeer (1981) suggested that the geographic distribution of this euphausiid in the eastern North Pacific determines that of the auklet - the sympatric ranges of prey and predator overlap completely, and extend from southeast Alaska to northern Baja California (cf. American Ornithologists' Union 1983, Brinton 1962, 1981).

Interannual variations in the availability of Thysanoessa spinifera during spring appear to explain variation in the auklet's reproductive phenology (Ainley \& Boekelheide 1990). The auklet must accumulate energetic reserves to allow egg formation. Laying occurs usually over a 2 to 3 wk period, with its onset ranging from early March to late May. The timing of egg laying is correlated with sea-surface temperature (SST). Once SST decreases to $10.5^{\circ} \mathrm{C}$ (affected by upwelling from the winter temperature range of 11 to $12^{\circ} \mathrm{C}$; Bolin \& Abbott 1963), auklet egg laying follows within $4 \mathrm{wk}$ (Ainley \& Boekelheide 1990).

The fact that egg laying follows an appreciable drop in SST indicates a role of coastal upwelling in the required increase of food availability. This SST drop is called the 'spring transition' (Huyer et al. 1979). If the transition is sharp: the entire population of auklets will lay eggs during a $<2 \mathrm{wk}$ period; if the transition is gradual, laying will be asynchronous and spread over a longer period (Ainley \& Boekelheide 1990). On the basis of these patterns, we hypothesize that the availability of food, likely defined by its vertical and horizontal distribution, is modified by intense upwelling. As discussed by Smith \& Adams (1988), the response by the euphausiids to upwelling could be related to trophic factors (e.g. increased primary production stimulating euphausiid growth or changing behavior for reproductive purposes) and/or physical ones (e.g. increased concentration by upwelling-induced fronts or at the edges of upwelling plumes; see also Briggs et al. 1988).

\section{METHODS}

We conducted this study in the Gulf of the FaralIones, from 1985 to 1988 , where the Cassin's auklet is one of the most abundant breeding species of seabird (Ainley \& Boekelheide 1990; Fig. 1). We designed the study to sample diet before and after the spring transition (March to April, or Julian dates 60 to 121; denoted as $T$ in various figures), throughout the following period of intense upwelling (May to July, or Julian dates 122 to 212 ; denoted as U), and during the nonupwelling portion of the year (August to February, or Julian dates 213 to 365 and 1 to 59 i denoted as N). It was fortunate for our purposes that the study period included one El Niño, 1986-87, albeit a weak one, because El Niño strongly affects variability of biological processes in the California Current (Glantz \& Thompson 1981). For reporting purposes, we also divided the year into several portions using the phenology of auklet reproduction (see Ainley \& Boekel- 
heide 1990) and upwelling (Bolin \& Abbott 1963, Bakun 1975), as follows: March to April (the midst of egg laying and immediately post spring transition; average date of egg laying in the study years was 4 April 1985, 18 April 1986, 9 April 1987, and 28 March 1988); May (late incubation, chick hatching, and period of most intense upwelling); June to July (main period of chick feeding, decrease in upwelling intensity); and August to February (post fledging, non-breeding period, and non-upwelling period).

Auklets were collected using a shotgun from areas of the Gulf that consistently supported known feeding concentrations (5 to 10 birds in each of 29 samples; see Figs. 1 \& 2). In the transition, upwelling, and non-upwelling periods, respectively, 63, 105, and 42 auklets were collected. We encountered auklets mostly along the edge of the continental shelf from Cordell Bank to just south of the Farallon Islands (see Fig. 3). For comparison with at-sea collections, we also obtained complete food loads from parents when they landed near their burrows to feed chicks on Southeast Farallon Island. Ten samples were obtained every $10 \mathrm{~d}$ through June and July each year during 1971 and 1977-1991. These samples were collected by having the auklet

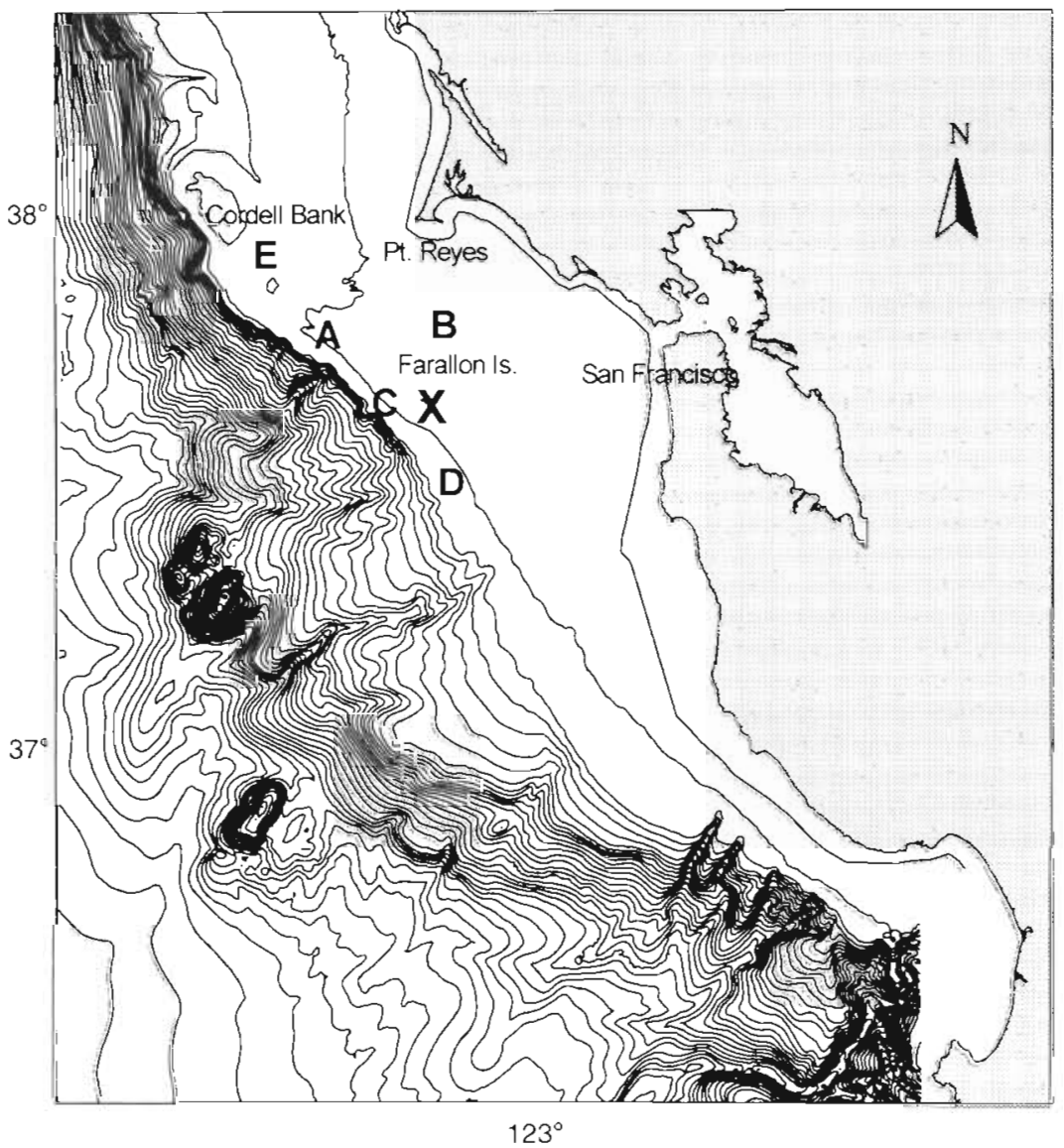

Fig. 1. Gulf of the Farallones off California, USA, showing sampling sites, with an $\boldsymbol{X}$ showing location of the region's only breeding site for Cassin's auklet Ptychoramphus aleuticus, the Farallon Islands; letters denoting different collecting sites are referred to in Fig 3. Isobaths are shown at each $50 \mathrm{~m}$ depth interval regurgitate into a plastic bag.

Upon collection of birds, stomachs and gular pouches were removed immediately and injected with ethanol to stop digestive processes. In most cases, prey items were identified and counted within $1 \mathrm{~h}$; or in a few instances, samples were frozen but were analyzed within 1 wk of collection. Regurgitation samples were frozen and analyzed at the end of the summer. In both types of samples, whole prey items were measured (standard lengths for fish and euphausiids, mantle lengths for cephalopods). Lengths and then masses were determined by regression of otolith diameter or length of the lower rostrum in the case of squid. Otoliths were included in analysis only if they showed no sign of digestion; squid beaks were included only if not abraded. Regression equations are reported elsewhere (Spear 1993, Ainley et al. in press).

A sample constituted all auklets or regurgitations obtained on à giveñ date al a given iocailty. We characterized diet on the basis of composition by number, by mass, and by frequency of occurrence (proportion of

samples in which a prey item occurred). We also characterized diet by calculating an index of relative importance (IRI), which is derived from a combination of percent composition by number, by mass, and by frequency of occurrence, to aid in comparisons of our data with those of certain other authors (see Pinkas et al. 1971, Day \& Byrd 1989, and Croll 1990 for the formula).

Diet similarity among samples was determined on the basis of percent composition by mass using Morisita's Index of Diet Overlap (see Baltz \& Morejohn 1977, Ainley \& Boekelheide 1990). Hereafter, the terms diet similarity and diet overlap are used interchangeably. We used diet as measured by mass in the comparison because mass is most often used to report foodweb relationships in biological oceanography. The above 2 references also report the formula for diet diversity that we calculated. We used results of the diot overlap analysis, presented as an icicle plot (Kruskal \& Landwehr 1983, Norusis 1986), in order to group samples. We opted for this method of graphical display 
because, better than dendograms, it shows well the actual degree of sample overlap/similarity. We used average-linkage-between-groups as the clustering algorithm (SPSS PC+; Norusis 1986). Following Diamond (1983) and Ainley et al. (1984, 1992), we considered diets to be equivalent if overlap exceeded $85 \%$. At approximately that point in frequency distributions of overlap indices, a distinct hiatus occurred among samples. All statistical tests performed were done using the statistical computer program STATA (Computing Resource Center 1989).

The distribution of auklets off central California was determined during June each year using ship-board censuses. At least 2 observers counted all auklets sitting on the water within $300 \mathrm{~m}$ of one forequarter whenever the ship was underway. Surveys were continuous through each day, but were grouped by location into 15 min segments. We calculated auklet density (birds $\mathrm{km}^{-2}$ ) for each segment. Using the curiputer program ARC/INFO (Version 6.1, ESRI, Inc., Redlands,
CA, USA), densities were averaged and plotted among all segments that occurred within any $5 \times 5 \mathrm{~km}$ (latitude $\times$ longitude) block.

\section{RESULTS}

A comparison of the at-sea densities of foraging auklets during June, among the years 1986, 1987, and 1988, indicated little interannual variation in foraging site (Fig. 2). Auklets were most concentrated over the shelf break, especially north of the South Farallones (the $\mathbf{X}$ in Fig, 1). In 1987, they were shifted southward somewhat. During El Niño 1986, foraging auklets were at densities $>10$ birds $\mathrm{km}^{-2}$ in 84 of the $5 \times 5 \mathrm{~km}$ blocks, compared to 58 and 61 blocks in 1987 and 1988, respectively, indicating that they were more dispersed in 1986.

Cluster analysis showed a clumping of diet samples by time but not locality - note in Fig. 3 the conjunction
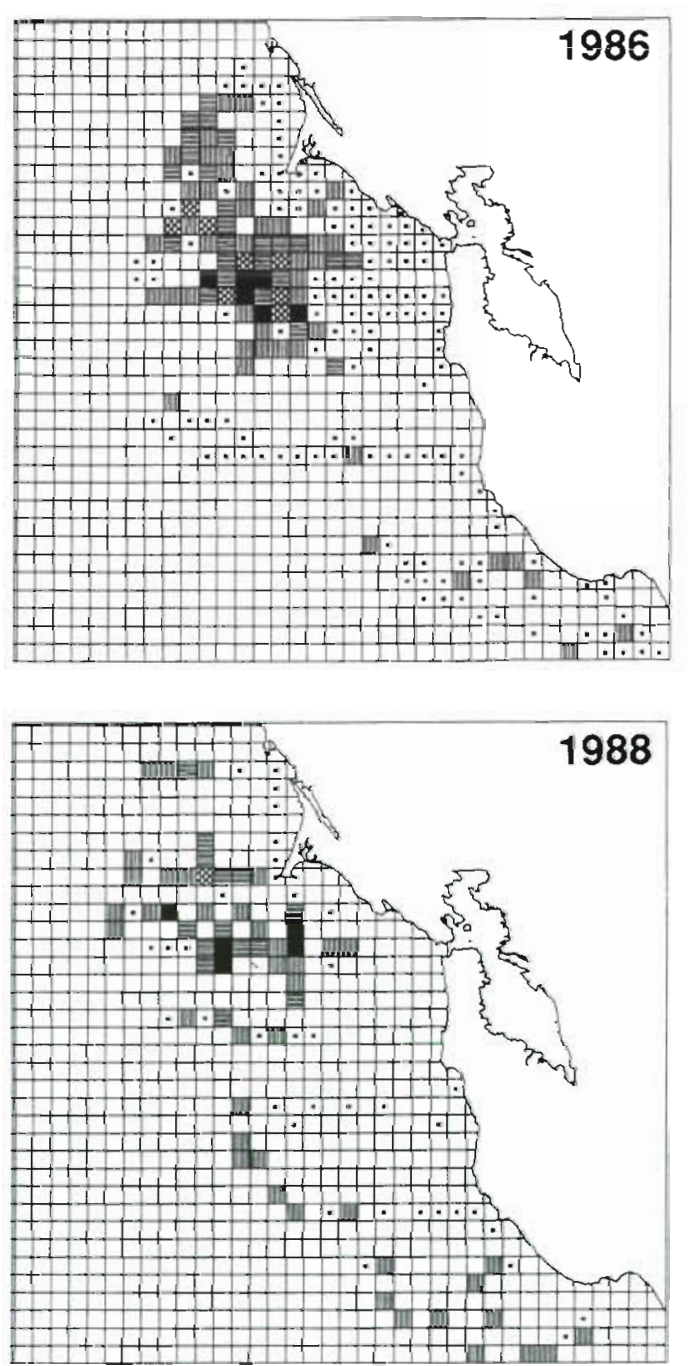
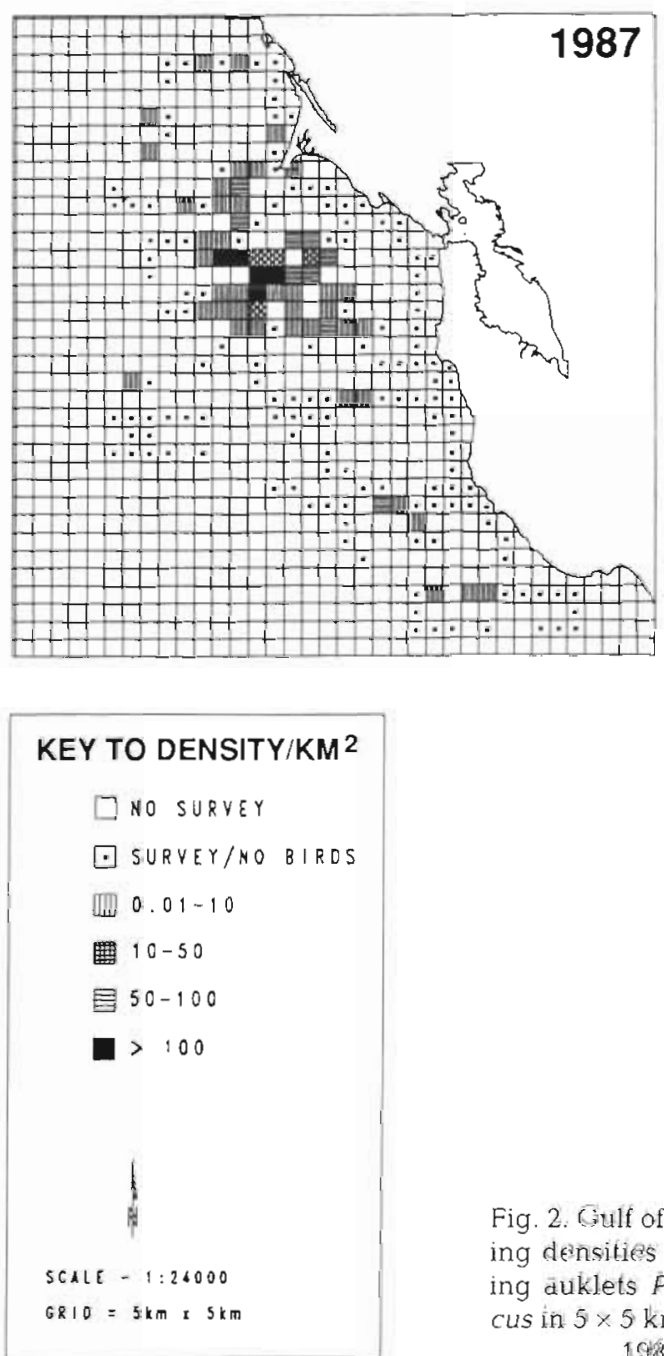

Fig. 2. Gulf of the Farallones, showing densities (birds $\mathrm{km}^{-2}$ ) of foraging auklets Ptychoramphus aleuticus in $5 \times 5 \mathrm{~km}$ blocks during 1986 , 1987 , and 1988 
PERCENT SIMILARITY BETWEEN ADJACENT SAMPLES

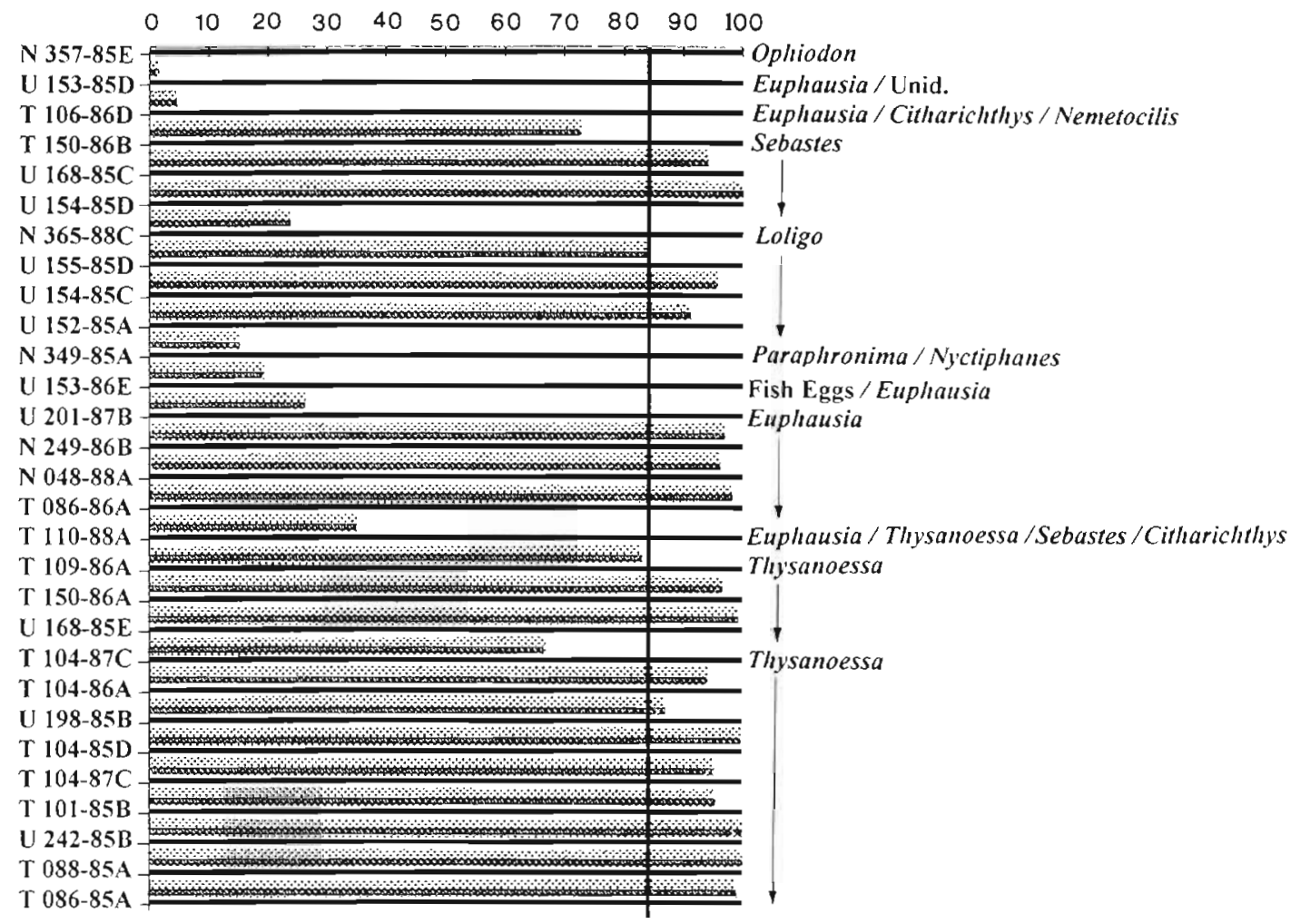

Fig. 3. Ptychoramphus aleuticus. Results of cluster analysis showing the degree of similarity among 29 samples of auklet stomach contents (dark horizontal lines) collected at different times and localities; shaded bar between samples shows degree of similarity (scale at top). Labeling to the left of the icicle plot, in order, shows oceanographic period ( $N$, non-upwelling; $T$, transition; U, upwelling), Julian date-year, and a letter (A to E) denoting locality shown in Fig. 1 Labeling to the right of the icicle plot shows the dominant prey of a sample; see Table 2 for complete names of prey. Similarity $>84 \%$ is deemed to be particularly strong (indicated by the solid, vertical line; see Ainley \& Boekelheide 1990, Ainley et al. 1992, Diamond 1983)

of the letters denoting seasonal identity of samples regardless of year and foraging site. This result indicated that within a mesoscale region (Figs. $1 \& 2$ ), the auklets moved to forage where prey were most available. Comparing samples grouped temporally, diets during May and JuneJuly differed (Table 1). The overlap index. indicated that diet during non-breeding/ non-upwelling was most similar to diets during April. This result, however, may be somewhat spurious and dependent on the larger samples collected in the non-breeding period 1985 ( 3 collections, 20 birds) vs 1987 and 1988 (1 collection each, 6 and 8 birds). In 2 of 3 non-breeding samples of years when diet data were also available for April, diets were clearly different from those in the corresponding April samples (1905, 19607, i9888; Fig. 4).

A review of prey items during the various periods indicated that 2 species of

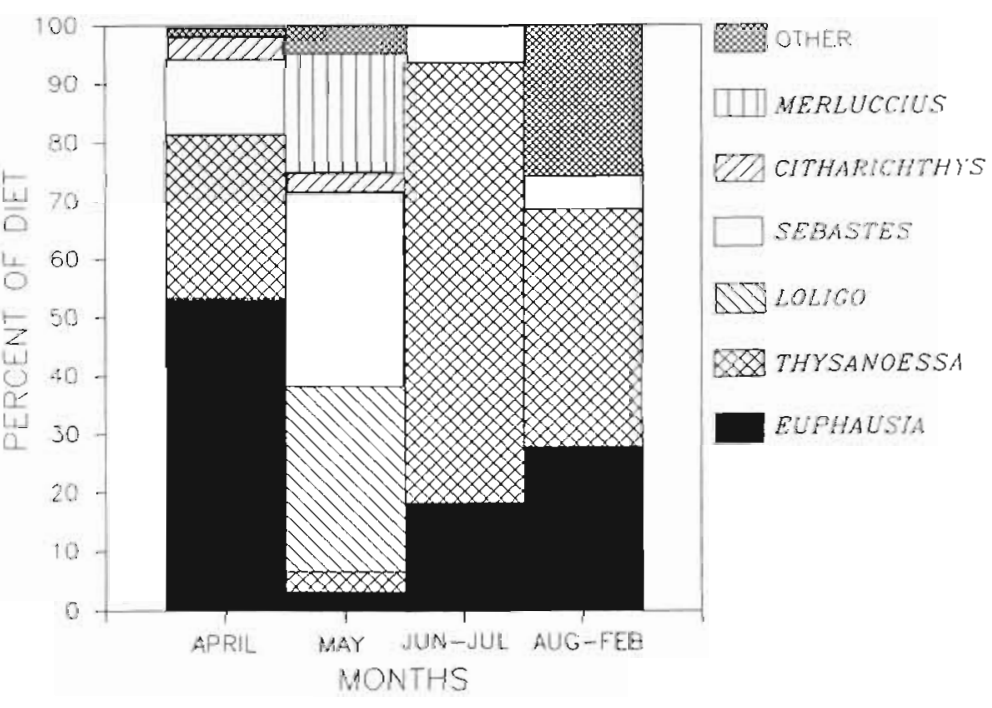

Fig. 4. Piychoraupinus dieuticus. Seasonal variation in the percent mass composition of the auklet diet in the Gulf of the Farallones; data combined for multimonth periods, all years combined. See Table 2 for complete names of prey 
Table 1 Ptychoramphus aleuticus. Morisita's Index of Diet Overlap, on the basis of percent composition by weight, among samples $(\mathrm{N}=181)$ partitioned by season

\begin{tabular}{|lccc|} 
& Mar-Apr & May & Jun-Jul \\
\hline May & 0.224 & & \\
Jun-Jul & 0.644 & 0.099 & \\
Aug-Feb & 0.819 & 0.135 & 0.400 \\
\hline
\end{tabular}

euphausiids, Thysanoessa spinifera and Euphausia pacifica, dominated the diet (Table 2). The importance of E. pacifica was greatest during the spring transition period and immediate post-spring transition period (Table 2, Fig. 4). The species became a minor item by the period of intense upwelling (May, June-July), increasing gradually over time as upwelling subsided. Conversely, $T$. spinifera reached greatest dietary inportance during the period of most intense upwelling (June and July, also the chick-rearing period).

The inclusion of small juvenile fish, especially during May, and of different crustacean species during August-February shifted the diet away from dominance by euphausiids (Fig. 4). Consequently, the diet during May and the non-upwelling period was the most diverse, a pattern repeated in the 2 years when data were available (Table 2, Fig. 5). The important fish during May included Sebastes spp. (especially), Citharichthys sordidus, Ophiodon elongatus, and Merluccius productus; small squid (likely Loligo opalescens) were also important during this time. Actually, Sebastes were represented in the diet year round; those early in the year were largely $S$. jordani (on the basis of trawl data from National Marine Fisheries Service during April-June: W. Lenarz \& S. Ralston unpubl. data; also see Larson et al. 1994) and the species occurring later in the diet were of unknown identity. Other crustaceans besides the above mentioned euphausiids included the euphausiids Nemetocilis difficilis and Nyctiphanes simplex, as well as larval Cancer magister and the amphipod Paraphronima gracilis.

Partitioning the diet samples at a finer temporal scale indicated substantial interannual variation during the 4 years (Fig. 5), but inclusion of fish in the diet during April and especially May was a recurring pattern. In the 3 June-July periods when we had data from both the parents collected at sea and the samples of chick feeds from parents on Southeast Farallon Island, a weak correspondence between results of the 2 sampling techniques was evident - the highest percent of Thysanoessa spinifera occurred in the third year for each: 39,6 , and $82 \%$ at sea compared to 22,27 , and $43 \%$ in the feeds. Our sampling was insufficient to
Table 2. The percent frequency of occurrence, percent composition by number and by mass, and the index of relative importance (IRI/100), partitioned by season of prey in the stomachs of Cassin's Auklets captured in the Gulf of the Farallones, 1985 to 1988

\begin{tabular}{|c|c|c|c|c|}
\hline Species & Frequency & yo. & Mass & IRI \\
\hline \multicolumn{5}{|c|}{ Mar-Apr $(\mathrm{N}=63$ birds $)-$ transitional period } \\
\hline Euphausia pacifica & 84.0 & 77.9 & 52.8 & 110 \\
\hline Thysanoessa spinifera & 31.7 & 18.6 & 27.8 & \\
\hline Nemetocelis difficilis & 4.8 & 2.4 & 1.1 & \\
\hline Paraphronima graculis & 3.2 & 0.1 & $<0.1$ & \\
\hline Cancer magister & 3.2 & 0.1 & $<0.1$ & \\
\hline \multicolumn{5}{|l|}{ Fish } \\
\hline Citharichthys sordidus & 7.9 & 0.2 & 4.2 & \\
\hline Sebastes spp. & 36.5 & 0.8 & 14.1 & \\
\hline Diversity" & & -0.66 & -1.15 & \\
\hline
\end{tabular}

May ( $N=50$ birds) - upwelling period Invertebrates

$\begin{array}{lrrrr}\text { Euphausia pacifica } & 57.1 & 46.9 & 3.4 & 29 \\ \text { Thysanoessa spinifera } & 33.3 & 10.1 & 2.3 & 4 \\ \text { Nyctiphanes simplex } & 11.9 & 27.4 & 0.8 & 3 \\ \text { Cancer magister } & 16.7 & 4.0 & <0.1 & 1 \\ \text { Loligo opalescens } & 16.7 & 1.7 & 32.4 & 6 \\ \text { Fish } & & & & \\ \text { Merluccius productus } & 11.9 & 1.0 & 21.8 & <1 \\ \text { Ophiodon elongatus } & 2.4 & 0.1 & 3.7 & <1 \\ \text { Citharichthys sordidus } & 23.8 & 1.0 & 2.5 & <1 \\ \text { Sebastesspp. } & 13.6 & 7.8 & 33.0 & 55 \\ \text { Diet diversity } & & -1.44 & -1.52 & \end{array}$

Jun-Jul ( $N=26$ birds) - upwelling period Invertebrates

$\begin{array}{lrrrr}\text { Euphausia pacifica } & 30.8 & 26.4 & 18.7 & 14 \\ \text { Thysanoessa spinifera } & 96.2 & 71.3 & 75.2 & 140 \\ \text { Nyctiphanes simplex } & 3.8 & 0.1 & 0.1 & 1 \\ \text { Cancer magister } & 3.8 & 0.1 & <0.1 & <1 \\ \text { Paraphronima gracilis } & 15.4 & 1.0 & <0.1 & <1 \\ \text { Pelecipod } & 3.8 & 0.1 & 0.1 & <1 \\ \text { Fish } & & & & \\ \quad \text { Sebastesspp. } & 26.9 & 1.0 & 5.9 & 2 \\ \text { Diet diversity } & & -0.71 & -0.71 & \end{array}$

Aug-Feb ( $N=42$ birds) - non-upwelling period Invertebrates

$\begin{array}{lrrrr}\text { Euphausia pacifica } & 57.1 & 51.9 & 28.4 & 46 \\ \text { Thysanoessa spinifera } & 45.2 & 31.0 & 40.7 & 32 \\ \text { Nemetocelis difficilis } & 4.8 & 0.1 & <0.1 & <1 \\ \text { Nyctiphanes simplex } & 14.3 & 5.4 & 1.7 & 1 \\ \text { Cancer magister } & 4.8 & 0.1 & <0.1 & <1 \\ \text { Paraphronima gracilis } & 19.0 & 10.1 & 2.8 & 1 \\ \text { Ish } & & & & \\ \text { Ophiodon elongatus } & 2.4 & 0.1 & 3.8 & <1 \\ \text { Sebastes spp. } & 19.0 & 0.3 & 5.0 & 1 \\ \text { Fish eggs } & 3.8 & 0.9 & 17.5 & <1 \\ \text { Diet diversity } & & -1.19 & -1.48 & \end{array}$

${ }^{a}$ Diet diversity determined on the basis of percent composition of both the number and mass of items in the diet 


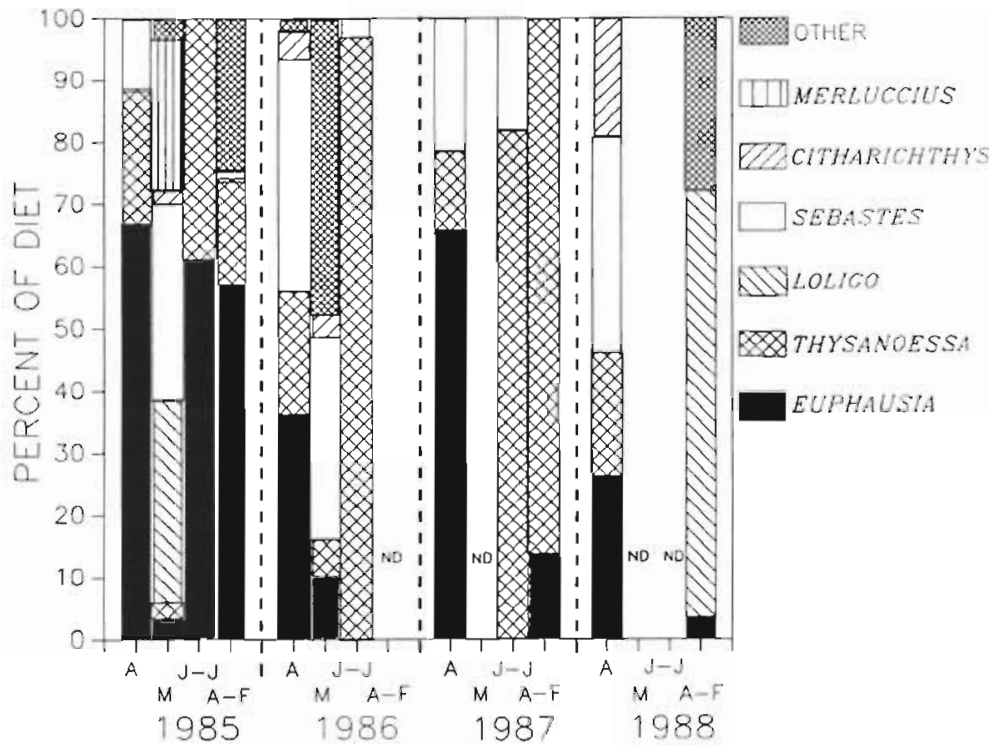

Fig. 5. Ptychoramphus aleuticus, Interannual variation in the percent mass composition of the auklet diet in the Gulf of the Farallones; data partitioned by months as well as by years, 1985 to 1988 (ND: no data). See Table 2 for complete names of prey cruises (a few days) and (2) the items brought by seabirds and pinnipeds to their young over an overlapping period of several weeks. The differences observed between these 2 studies may well be due to the better ability of seabirds to integrate characteristics of prey populations over time and space; the trawl samples, however, can compile complementary data on depth distribution, etc. Croxall et al. (1985) concluded that the predators and the trawlers were perhaps fishing in a different manner. This, however, was not an aspect of our comparison. In our Gulf of the Farallones studies, parent-derived samples at the colony correlated well with patterns in the life history of the seabirds (Ainley \& Boekelheide 1990), a result not evident among the at-sea derived collections. Apparently, our at-sea samples were too sporadic to characterize any but the broad-scale patterns. After all, atsea collections record what was taken at a specific time and location, whereas the denote any patterns with respect to the weak El Niño (1986-87), but changes, if any, were slight. The only effect appeared to be a slight delay in the onset of upwelling as indicated by the later auklet egg-laying dates (Point Reyes Bird Observatory unpubl. data).

The auklets ate adult euphausiids throughout the year. On the other hand, the age (and size) of the Sebastes caught by the auklets changed with season (Fig. $6 ; \chi^{2}=246.14, p=0.0001, \mathrm{~d} f=6$ ). The auklets were probably eating the same stock of young in both April and May, as the May fish were larger than those eaten earlier. Late in the summer, it appeared that any Sebastes eaten may have come from a different spawning, or perhaps were of other species than those eaten earlier (different species of rockfish extrude their young at different times of the year; Wyllie Echeverria 1987). The other fish and squid species eaten were all $<80 \mathrm{~mm}$ standard length.

\section{DISCUSSION}

The lack of correspondence in results from the collections at sea, obtained in relatively limited periods, and the results from parental feeds, obtained over a broader but overlapping time frame, is a phenomenon similar to that reported by Croxall et al. (1985). The latter authors compared characteristics of euphausiid popuilations anvund Soutin Georgla on the basis of (1) trawl samples obtained during a limited time period but one of a length characteristic of typical fisheries
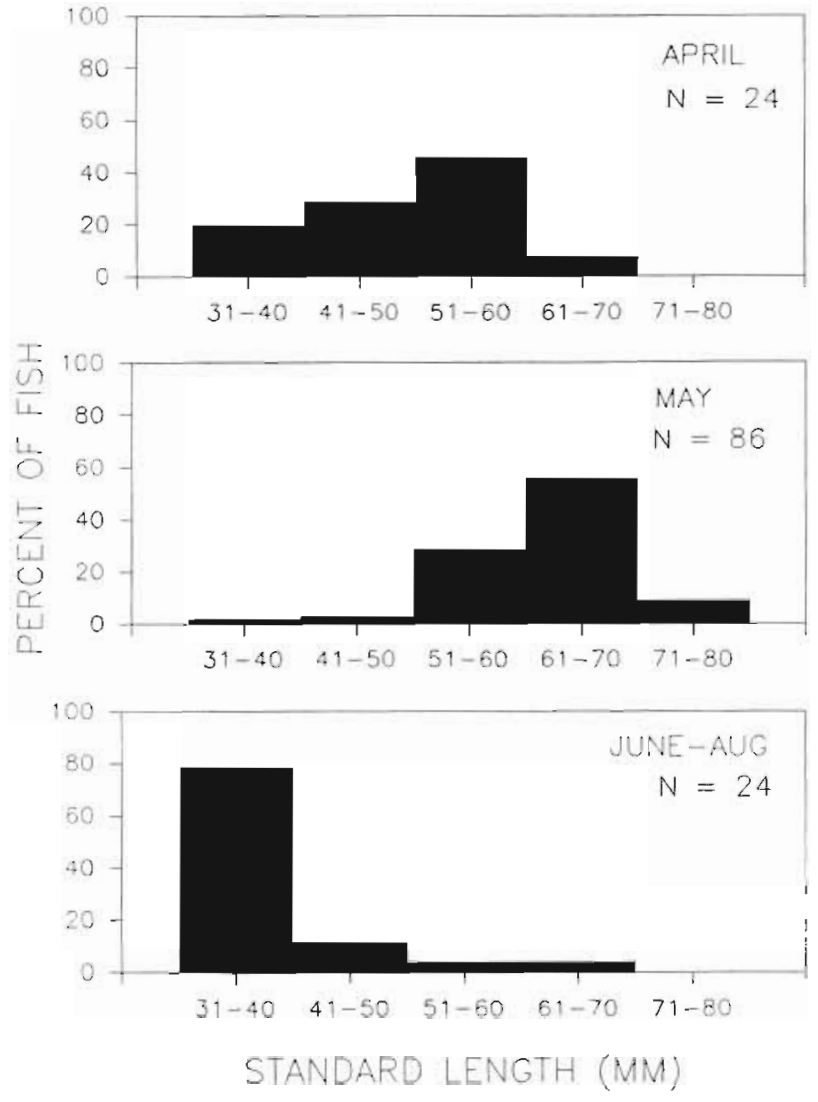

Fig. 6. Size-fièquency distribution of rockfish Sebastes spp. taken by auklets Ptychoramphus aleuticus in the Gulf of the Farallones, by seasonal period; standard lengths of fish reconstructed by regression against otolith diameter 
colony samples integrate a much broader area, i.e. the Gulf of the Farallones, and a broader time interval, i.e. samples taken regularly for $6 \mathrm{wk}$.

Nevertheless, the results of the at-sea collections reported herein revealed information not possible to obtain from the parental chick-feeding samples of midsummer, as reported in detail elsewhere (Manuwal 1974, Vermeer 1981, Ainley \& Boekelheide 1990). Particularly during May, the auklets selected small, young fish over euphausiids. Both the fish and the euphausiids occur within the same swarms (author's pers. obs. on basis of trawls by the US National Marine Fisheries Service, the same cruises as our auklet censusing). Energetically, such selection may be a better strategy because the fish are more valuable per unit expenditure of capture effort: the fish are slightly larger and have a higher caloric value per unit weight (see energetic comparison of these items in Spear 1993). Prey selection by seabirds on the basis of caloric value has been observed only a few times among seabirds (e.g. Montevecchi \& Piatt 1984, Barrett \& Furness 1990, Ainley et al. 1992, in press). The auklets ceased to feed on fish by June, although the larger common murre Uria aalge (a murre's bill is $60 \mathrm{~mm}$ long, or 2 times larger than an auklet's), which was also feeding in the vicinity on small fish, continued to do so as the fish grew (Ainley et al. in press). On the basis of trawls, the fish were abundant near the surface at this time (e.g. Larson et al. 1994). Thus, it was not a disappearance of

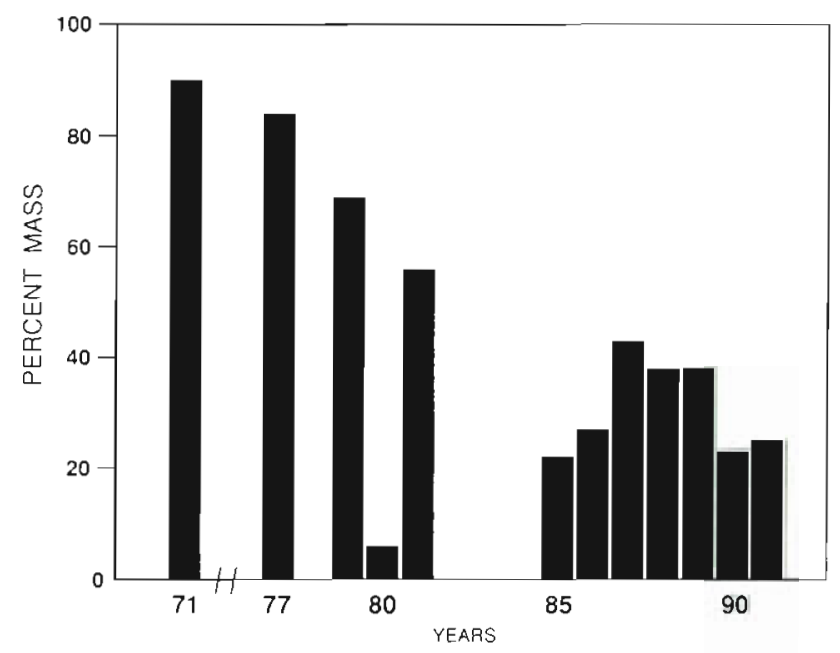

Fig. 7 Percent contribution by mass of Thysanoessa spinifera to the diet fed to auklet Ptychoramphus aleuticus chicks, 1971 and 1977-1991 $\left(\mathrm{r}^{2}=0.524, \mathrm{p}=0.008, \mathrm{df}=10\right)$; prevalence of Euphausia pacifica in the diet showed the opposite trend. Except for the period 1972 to 1976 (when no effort was expended toward collecting data), years lacking data were those in which auklets did not breed in sufficient number to collect diet samples the fish that forced the switch from fish to euphausiids by the auklet.

The smaller Euphausia pacifica dominated auklet diets during April and often during the preceding months as well, probably because this euphausiid is the largest, most available and suitable prey. By June, once the fish had surpassed the appropriate size, the auklets switched to Thysanoessa spinifera, which is twice the size of E. pacifica and, thus, again is the better energetic choice. We would presume that the auklets would always feed on the larger $T$. spinifera, if they had the opportunity to do so. Alternatively, the coastal upwelling front (see Schwing et al. 1991) may also play a role in forcing a switch to $T$ spinifera (for energetic reasons) by forcing the oceanic E. pacifica to occur too far away from the colonies for them to be a practical resource for the auklets.

Our results show that the spring transition marks the time after which Thysanoessa spinifera becomes readily available to predators in the Gulf of the Farallones. Heretofore, a relationship to upwelling was left to conjecture (e.g. Smith \& Adams 1985). Additional, indirect evidence that upwelling plays a significant role in affecting the availability of euphausiids to auklets is the coincidence of several trends in the California Current since the late 1970s: (1) a marked decline in population size of the auklet at the Farallones (Carter et al. 1992, Ainley et al. 1994); (2) diminished intensity of upwelling (as seen in Fig. 2 of Bakun 1990); (3) increased SST (Roemmich \& McGowan 1995); (4) a general decline in the abundance of zooplankton. (Roemmich \& McGowan 1995); and (5) a decrease in prevalence of $T$. spinifera in the auklet diet fed to chicks (Fig. 7). Evidence exists for a similar decrease in the auklet population during a period of generally warmer waters in the late middle portion of the 19th century, as described by Hubbs (1960); and, with return of cooler waters in the late century, the auklet population rebounded (Ainley \& Lewis 1974). The processes by which the onset and duration of upwelling affect development of the coastal food web in the California Current region, particularly in regard to euphausiids, remain a research field where further work is needed. As part of this work, further investigation of Cassin's auklets will likely be fruitful.

Acknowledgements. We thank, especially, personnel of the National Marine Fisheries Service-Tiburon Laboratory, particularly W. Lenarz, S. Ralston, D. Woodbury, P. Adams, and S. Smith, for making room for us on their rockish assessment cruises aboard the NOAA ship 'David Starr Jordan'; for designing cruises inadvertently to suit our purposes; and for much discussion on the biology of the bird prey caught in their trawls, 1985 to 1994 . We especially thank S. Smith and W. Peterson for insights into euphausiid biology and identification of crustaceans. The NMFS personnel also provided many of the specimens we used to develop size-mass regres- 
sion equations, Indispensable as well were the many ocean trips provided to us by $H$. Corning and $T$. Beeson, and the efforts of PRBO Farallon biologists to collect auklet regurgitations. Financial support for our field work was provided by the Gulf of the Farallones National Marine Sanctuary, Minerals Management Service, US Fish and Wildlife Service (Farallon Refuge), and NSF grant OCE 8911125 . R. Ferris assisted greatly in the collection and sorting of samples. Auklets were collected under permits from the US Fish and Wildlife Servıce and the California Department of Fish and Game. Preparation of the manuscript was funded in part by a grant from the State of California, Office of Oil Spill Prevention and Response. G. L. Hunt, S. Smith, W. Sydeman, and 2 anonymous reviewers kindly offered comments on the manuscript.

\section{LITERATURE CITED}

Ainley DG, Boekelheide RJ (eds) (1990) Seabirds of the Farallon Islands: structure and dynamics of an upwelling-system community. Stanford Univ Press, Stanford, CA

Ainley DG, Lewis TJ (1974) The history of Farallon Island marine bird populations: 1854-1972. Condor 76:432-446

Ainley DG, O'Connor EF, Boekelheide RJ (1984) The ecology of birds in the Ross Sea, Antarctica. Ornithol Monogr 32

Ainley DG, Ribic CA, Fraser WR (1992) Does prey preference affect habitat choice in Antarctic seabirds? Mar Ecol Prog Ser 90:207-221

Ainley DG, Spear LB, Allen SG, Ribic CA (in press) Temporal and spatial patterns in the diet of common murres in California waters. Condor

Ainley DG, Sydeman WJ, Hatch SA, Wilson UW (1994) Seabird population trends along the west coast of North America: causes and the extent of regional concordance. Stud Avian Biol 15:119-133

Ainley DG, Sydeman WJ, Norton J (1995a) Upper trophic level predators indicate interannual negative and positive anomalies in the California Current food web. Mar Ecol Prog Ser 118:69-79

Ainley DG, Veit RL, Allen SG, Spear LB, Pyle P (1995b) Variations in marine bird communities of the Calıforna Current, 1986-1994. Calif Coop Ocean Fish Investig Rep 36 $72-77$

Alversen DL, Larkins HA (1969) Status of knowledge of Pacifıc hake resource. Calıf Coop Ocean Fish Investig Rep 13:24-31

American Ornithologists' Union (1983) Check list of North American birds, 6 th edn. Allen Press, Lawrence, KS

Bakun A (1975) Daily and weekly upwelling indices, west coast of North America, 1967-73. US Dept Commerce, NOAA Tech Rep NMFS SSRF-693, La Jolla, CA

Bakun A (1990) Global climate change and intensification of coastal ocean upwclling. Scrence 247:198-201

Baltz DM. Morejohn GV (1977) Food habits and niche overlap of seabirds wintering on Monterey Bay, California. Auk 94:526- -543

Barber RT. Chavez FP (1986) Ocean variability in relation to living resources during the 1982-83 El Niño. Nature 319: 279-285

Barrett RT, Furness RW (1990) The prey and diving depths of seabirds on Hornoy, north Norway, after a decrease in the Barents Sea capelin stocks. Ornis Scand 21:179-186

Bolin RL, Abbott DP (1963) Studies on the marine climate and phytoplankton of the coast of Califnrnia, 1954-1960. Calif Coop Ocean Fish Investig Rep 9:23-45

Briggs KT, Ainley DG, Spear LB, Adams PB, Smith SE (1988) Distribution and diet of Cassin's auklet and common murre in relation to central California upwellings. In: Ouellet $H$ (ed) Acta XIX Congressus Internationalis Ornithologici, Vol 1. National Museum of Natural Science, Ottawa, p $982-990$

Brinton E (1962) The distribution of Pacific euphausiids. Bull Scripps Inst Oceanogr 8:51-270

Brinton E (1981) Euphausiid distributions in the California Current during the warm-water spring of $1977-78$, in the context of a 1949-66 time series. Calif Coop Ocean Fish Investig Rep 22:135-154

Cairns D (1992) Bridging the gap between ornithology and fisherles science: use of seabird data in stock assessment models. Condor 94:811-824

Carter HC, McChesney GJ, Jaques DL, Strong CS, Parker MW, Takekawa JE, Jory DL, Whitworth DL, Point Reyes Bird Observatory and Channel Islands National Park (1992) Breeding populations of seabirds on the northern and central California coasts in 1989 and 1990. US Dept Interior, Minerals Management Service, Los Angeles, CA

Chu EW (1982) Sooty shearwaters off California: diet and energy gain. In: Nettleship DN, Sanger GA, Springer PF (eds) Marine birds: their feeding ecology and commercial fisheries relationships. Spec Publ, Canad Wildl Serv, Ottawa, p 64-71

Computing Resource Center (1989) STATA: reference manual, 4 th edn. Computing Resource Center, Santa Monica, CA

Crawford RJM, Shelton PA (1978) Pelagic fish and seabird interrelationships off the coast of South West and South Africa. Biol Conserv 14:85-109

Croll DA (1990) Physical and biological determinants of the abundance, distribution, and det of the common murre in Monterey Bay, California. Stud Avian Biol 14:139-148

Croxall JP, Prince PA, Ricketts C (1985) Relationships between prey life-cycles and the extent, nature and timing of seal and seabird predation in the Scotia Sea. In: Siegfried WR, Condy PR, Laws RM (eds) Antarctic nutrient cycles and food webs. Springer-Verlag, Berlin, p 516-533

Day RH, Byrd GV (1989) Food habits of the whiskered auklet at Buldir Island, Alaska. Condor 91:65-72

Diamond AW (1983) Feeding overlap in some tropical and temperate seabird communities. Stud Avian Biol 8:24-46

Furness RW, Greenwood JJD (eds) (1993) Birds as monitors of environmental change. Chapman and Hall, London

Furness RW, Monaghan P (1985) Seabird ecology. Blackie, Glasgow

Glantz MH, Thompson JD (eds) (1981) Resource management and environmental uncertainty: lesson from coastal upwelling fisheries. Wiley-Interscience, New York

Hubbs CL (1960) The marine vertebrates of the outer coast. Syst Zool 9:134-1.47

Hunt GL, Piatt JF, Erikstad KF (1991) How do foraging seabirds sample the environment? Congr Internatl Ornithol, Acta XX:2272-2279

Huyer A, Sobey EJ, Smith RL (1979) The spring transition in currents over the Oregon contunental shelf. J Geophys Res $84: 6995-7011$

Karpov K, Cailliet GM (1978) Feeding dynamics of Loligo opalescens. In: Recksiek CW, Frey HW (eds) Biological, oceanographic, and acoustic aspects of the market squid, Loligo opalescens Barry. Calif Dept Fish Game Fish Bull 169:45-66

Kickfffer T (1992j Feeding ecology of humpback whales in continental shelf waters near Cordell Bank, California. MSc thesis, Moss Landing Marine Laboratory, San Jose State Univ, San Jose, CA 
Kruskal JB, Landwehr JM (1983) Icicle plots: better displays for hierarchical clustering. Am Stat 37:162-168

Larson RJ, Lenarz WH, Ralston S (1994) The distribution of pelagic juvenile rockfish of the genus Sebastes in the upwelling region of central California. Calif Coop Ocean Fish Investig Rep 35:175-221

MacCall AD, Frey HW, Huppert DD, Knaggs EH, McMillan JA, Stauffer GD (1980) Biology and economics of the fishery for jack mackeral in the northeastern Pacific. US Dept Commerce, NOAA Tech Mem NMFS, NOAA-TM-NMFSSWFC $4: 1-79$

Manuwal DA (1974) The natural history of Cassin's auklet. Condor 76:421-431

Monaghan P, Uttley JD, Burns MD, Thaine C, Blackwood J (1989a) The relationship between food supply, reproductive effort and breeding success in Arctic terns Sterna paradisaea. J Anim Ecol 58:261-274

Monaghan P, Uttley JD, Okill JD (1989b) Terns and sandeels: seabirds as indicators of changes in marine fish populations. J Fish Biol 35 (Suppl A):339-340

Montevecchi WA, Piatt J (1984) Composition and energy contents of mature inshore spawning capelin (Mallotus villosus): mplications for seabird predators. Comp B̈iochen Physiol 78:15-20

Norusis, MJ (1986) SPSS PC+ advanced statistics. SPSS Inc, Chicago

Peterson WT, Brodeur R, Pearcy WG (1982) Diets of juvenile salmon in the Oregon upwelling zone in June 1979. Fish Bull US 80:841-851

Phillips JB (1964) Life history studies on ten species of rockfish (genus Sebastodes). Calif Dept Fish Game Fish Bull 126: $1-70$

Pinkas L, Oliphant MS, Iversen ILK (1971.) Food habits of

This article was submitted to the editor ali)dcore, bluefin tuna, and bonita in California waters Caluf Dept Fish Game Fish Bull 152:1-105

Reilly CA, Wyllue Echeverra T, Ralston S (1992) Interannual variation and overlap in the diets of pelagic juvenile rockfish (Genus: Sebastes) off central California. Fish Bull US 90:505-515

Ribıc CA, Ainley DG, Spear LB (1990) Effects of El Niño and La Niña on seabırd assemblages in the Equatorial Pacific. Mar Ecol Prog Ser 80:109-124

Roemmich D, McGowan J (1995) Climatic warming and the decline of zooplankton in the California Current. Science 267:1324-1326

Schreiber EA, Schreiber RW (1989) Insights into seabird ecology from a global 'natural experiment' Natl Geogr Res 5 $64-81$

Schwing FB, Husby DM, Garfield N, Tracy DE (1991) Mesoscale oceanic response to wind events of central California in spring 1989: CTD surveys and AVHRR imagery Calif Coop Ocean Fish Investig Rep 32:47-64

Smith SE, Adams PB (1988) Daytime surface swarms of Thysanoessa spinifera (Euphausicacea) in the Gulf of the Farallones, California. Bull Mar Sci 42:76-84

Spear LD (1003) Dynamirs and effect of western gulls feeding in a colony of guillemots and Brandt's cormorants. J Anin Ecol 62:399-414

Vermeer K (1981) The importance of plankton to Cassin's auklets during breeding. J Plankton Res 3(2):315-329

Vermcer K (1985) A. five-year summary (1978-1982) of the nestling diet of Cassin's auklets in British Columbia. Can Tech Rep Hydrogr Ocean Sci 56

Wyllie Echeverria $T$ (1987) Thirty-four species of California rockfishes: maturity and seasonality of reproduction. Fish Bull US 85:229-250

Manuscript first received. October 5, 1995

Revised versıon accepted: December 8, 1995 